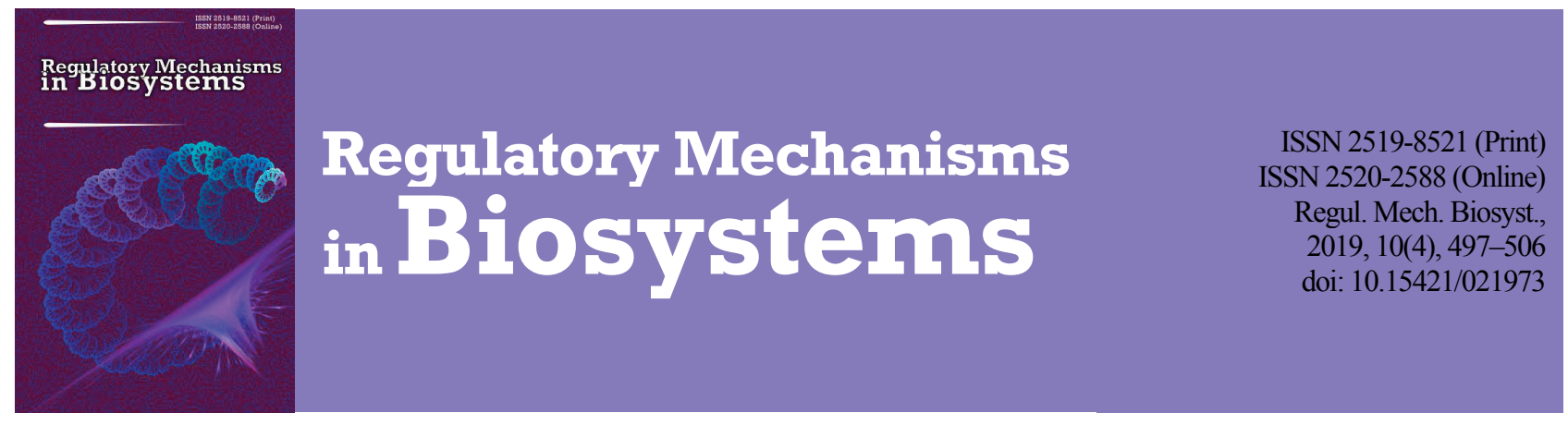

\title{
Effect of alcohol tincture of Aralia elata on the organism of rats and their gut microbiota against the background of excessive fat diet
}

\author{
V. V. Brygadyrenko*, M. A. Lieshchova**, M. V. Bilan**, N. M. Tishkina**, A. V. Horchanok** \\ * Oles Honchar Dnipro National University, Dnipro, Ukraine \\ **Dnipro State Agrarian and Economic University, Dnipro, Ukraine
}

Article info

Received 15.09.2019

Received in revised form 17.10.2019

Accepted 18.10.2019

Oles Honchar Dnipro National University, Gagarin av., 72, Dnipro, 49010, Ukraine. Tel.: +38-050-93-90-788. E-mail:brigad@ua.fm

Dnipro State Agrarian and Economic University, Serhii Efremov st., 25, Dnipro, 49600, Ukraine. Tel.: + 38-056-268-54-17 E-mail:

lieshchova.m.o@dsau.dp.ua
Brygadyrenko, V. V., Lieshchova, M. A., Bilan, M. V., Tishkina, N. M., \& Horchanok, A. V. (2019). Effect of alcohol tincture of Aralia elata on the organism of rats and their gut microbiota against the background of excessive fat diet. Regulatory Mechanisms in Biosystems, 10(4), 497-506. doi:10.15421/021973

Pharmacological effects of the medicinal plant Aralia elata (Miq.) Seem. 1868 (Araliaceae) are related to presence of over 150 secondary metabolites, including flavonoids, sterols, polysaccharides, terpenoid saponins and terpenoid acids, though the main biologically active substances of $A$. elata are saponins and flavonoids. Some clinical tests and experimental studies have proved the influence of $A$. elata on the organism through increase in physical work capacity, exerting an anti-stress effect against a broad range of harmful factors, including stress from cold, immobilization, ultraviolet radiation and low pressure. The literature also reports the anti-ulcer, anti-secretory, antifungal, anti-tumour, and antimicrobial activity of preparations from this plant. In our laboratory experiment, we determined that ethanolic tincture of $A$. elata has no effect on the intensity of growth of body weight of young rats against the background of excessive content of fat in their diet. Excessive fat-feeding of male rats leads mostly to disorders in the functioning of the liver and development of steatosis. This was accompanied by reduction in relative mass of the liver, increase in activity of hepatic enzymes, dysproteinemia, increase in the level of bilirubin and decrease in the level of urea. Additional use of $0.1 \%$ ethanol led to impaired functioning of the kidneys, reduction of their relative mass, signs of dehydration, increase in the level of creatinine and total calcium in the blood. Use of ethanolic tincture of $A$. elata mitigates negative excess of fat, is accompanied by normalization of indices of mass of the organs, less notable dysproteinemia, impairment in the level of creatinine, glucose, urea, cholesterol, bilirubin and total calcium. Ethanolic tincture of $A$. elata has a low immunosuppressive action, against the background of a high fat diet it leads to increase in the amount of typical Escherichia coli, decrease in Enterococcus spp. and Enterobacter spp., significant decrease and in high concentrations ( $0.1 \%$ ethanolic tincture of $A$. elata) elimination of bacteria of Clostridium and Klebsiella genera, and also various yeast fungi in the intestine. In the examined male rats, against the background of excess of fat in the diet, no serious changes in the composition of the normal gut microbiota (Bifidobacterium spp., Lactobacillus spp., Proteus spp., Staphylococcus spp., Candida spp.) was observed, nor were any lactosenegative enterobacteria (Citrobacter genus) found. Perspectives of further research include determining histological, histochemical and immune-histological changes in the organs of laboratory animals under the effect of ethanolic tincture of $A$. elata following excessive accumulation of fat.

Keywords: relative mass of the organs; increase in the body weight; gut microbiota; microbiome; high-fat diet.

\section{Introduction}

The widely known medical plant Aralia elata (Miq.) Seem. 1868 (commonly called Japanese anjelica tree, also known as Manchurian aralia tree Aralia mandshurica Rupr. et Maxim.) of the Araliaceae family is a tree or bush (up to $10 \mathrm{~m}$ in height), distributed in the North-East regions of China, Japan, Korea and the Far East of the Russian Federation. Traditionally, for medical purposes, roots of the plant are used, more rarely - leaves and bark. Currently, roots of $A$. elata are used in classic pharmacology of many countries. They are processed into alcoholic tinctures and tablets, or included in the composition of some complex preparations. Tinctura Araliae is an ethyl tincture (70\%), standardized, available at the pharmacy on prescription and is recommended for oral administration at a dose of $0.75-1.00 \mathrm{~mL}$ twice a day. Saparal tablets are pure extract of roots of A. elata, each containing $50 \mathrm{~mL}$ of mixture of ammonia salts of aralosides A, B and C. The preparation is for oral administration in the dose of one tablet twice a day. Arfazetin is a mixture of different types of plants, including root of Aralia (15\%); it is recommended as a hypoglycemic preparation (Shikov et al., 2016). Pharmacological effects of the plant are related to the presence of over 150 secondary metabolites, including flavonoids, sterols, polysaccharides, terpenoid saponins and terpenoid acids (Guo et al., 2009; Wang et al., 2011; Clement \& Clement, 2015). However, the main biologically active substances of $A$. elata are saponins and flavonoids (Zhang \& Song, 2012; Zhang et al., 2013, 2018; Wang et al., 2014). In their studies, Saito et al. (1993), out of 11 saponins in the leaves of $A$. elata, studied the most active ones, those which reduced the aspartate aminotrasferase (AST) and alanine aminotrasferase (ALT) production by hepatocytes during $\mathrm{CCl}_{4}$-induced hepatitis in rats (Saito et al., 1993). Furthermore, saponins extracted from leaves of A. elata had significant anti-tumour action in humans with mammary gland cancer - both in vivo and in vitro (Li et al., 2019). Today, complex spectral analysis has distinguished new triterpene saponins (congmusaponin I, II, III, congmuyenoside V, congmuyenoside VI), their inhibiting activity towards enzymes $\alpha$-glucosidase, protein tyrosine phosphatase 1B (PTP1B) and neuroprotective effects have been determined (Zhang et al., 2018a, b).

Medicinal plants with complex compositions of saponins, flavonoids and alcoloids can cause side-effects or synergic effects over chemical interactions in the organism of animals and humans (Saad, 2006). Therefore, for confirming safety of chemical substances from A. elata 
for humans, a number of toxicological surveys on experimental animals have been performed, the toxicity and allowable doses of medical preparation for humans have been determined (Li et al., 2015, 2016). On mice, during acute peroral delivery of alcohol tincture $(70 \%), \mathrm{LD}_{50}$ was determined to equal $1.25 \mathrm{~g} / \mathrm{kg}$ (Turova, 1974). According to the data by Pivovarova \& Lesiovskaya (2003), for commercial alchohol tincture (70\%) the root of Aralia (1 part) : alcohol (5 parts) in subcutaneous injection equaled $6.3 \pm 0.7 \mathrm{~mL} / \mathrm{kg}$. The chronic toxicity of alcohol tincture of A. elata was studied for rats which received it in injections during four weeks in daily doses of $0.25,0.50$ and $1.00 \mathrm{~g}$ per $1 \mathrm{~kg}$ of body weight. These doses did not lead to lethal effect or any clinical manifestations, also no changes in the internal organs were found during autopsy, nor changes in biochemical and morphological parameters of blood and urine analyses (Jin et al., 2006). While determining acute toxicity of alcohol extract from leaves of $A$. elata in rats which received peroral introduction of doses of 1.00, 2.15, 4.64 and $10.00 \mathrm{~g} / \mathrm{kg}$, Li et al. (2015) behavioural disorders and toxic syndrome were observed with lethal outcome in 14 days. Peroral introduction of those doses also caused various side-effects, and mortality increased in relation to increase in the dose of the preparation (Li et al., 2015).

Despite lack of knowledge on the mechanism of action, some clinical tests and experimental studies have confirmed that use of $A$. elata preparations increase physical working capability and have an antistress effect against a broad range of harmful stress factors, including stress from cold, immobilization, ultraviolet radiation, low atmospheric pressure. This phytoadaptogen affects the central nervous system (CNS), reproductive, immune, respiratory and digestive systems, optimizes the course of metabolic syndrome, showing hypolipidemic and anti-diabetic effects by changing blood coagulation (Shikov et al., 2016; Lee et al., 2019).

Tincture of $A$. elata is a familiar adaptogen, therefore a major part of its effects on the organism is related to general properties of Araliacontaining preparations. They are regulators of metabolism, which increase the ability of the organism to adapt to various stress factors of the environment and prevent damage caused by stresses (Panossian et al., 1999). Phytoadaptogens in small and average doses stimulate CNS, and in higher doses have a sedative effect (Montiel-Ruiz et al., 2012; Panossian et al., 2012). Data on the influence of A. elata on CNS are contradictory. A stimulating effect on the nervous system was induced by intragastric introduction of alcohol tincture of $A$. elata. During a course of injections, Saparal and Tinctura Araliae preparations increased general moving and exploring activity of animals in the "Open field" test, most notable changes occurred following consumption of alcohol tincture of the plant. Emotional status of male rats in all experimental groups was higher than in the control, and decrease in cosmetic activity in experimental groups was probably related to increase in general moving activity of the animals (Kharin et al., 2011). Extract of $A$. elata, given to mice intraperitoneally (in the dose of 10,30 and $100 \mathrm{mg} / \mathrm{kg}$ ) 30 minutes before taking pentobarbital prolonged time of narcosis, confirming the inhibitory effect on CNS. However, high doses of the extract $(100 \mathrm{mg} / \mathrm{kg})$ in groups of female mice somewhat reduced this time (Ahumada et al., 1991). Introduction of alcohol extract of Aralia root $(0.5 \mathrm{~g} / \mathrm{kg})$ and sodium 5,5-diethylbarbiturate $(0.15 \mathrm{mg} / \mathrm{g})$ at the same time reduced time of narcosis by $38 \%$ (Brekhman, 1963).

Adaptogenic effect of A. elata (commercial and non-commercial forms of alcohol tincture) in cases of hypobaric hypoxia has been determined on mice (Pospelova \& Barnaulov, 2000). Dilatometric surveys (Stjopin et al., 2019) also revealed high antiradical activity of alcohol tincture of the plant, by these indicators, it was inferior only to tincture of Eleutherococcus senticosus (Rupr. \& Maxim.) Maxim.

Anti-ulcer and anti-secretory properties of extract from Aralia were studied with animal models (laboratory rats) with peptic ulcer disease. Preliminary treatment with the plant $(50 \mathrm{mg} / \mathrm{kg}$ intraperitoneally) reduced the frequency and severity of lesions of the glands of the stomach (caused by cold stress), significantly decreased secretory volume of the stomach (by $40 \%$ ), increased $\mathrm{pH}$ of the stomach and decreased acid reflux by $81 \%$ (Hernandez et al., 1988). Studies on laboratory mice with non-alcohol steatohepatitis caused by diet with high content of fat, confirmed the healing effect of arazolides from $A$. elata, isolated from the plant's roots (Luo et al., 2015). Molecular mechanisms of anti-inflam- matory and anti-apoptotic action have been studied and general protective effect of saponins of $A$. elata was proved in cases of damage to endothelial cells of blood vessels on the example of endothelium of the umbilical vein of a human, affected by necrosis factor- $\alpha$ (TNF- $\alpha$ ) (Zhou et al., 2018).

A number of researchers found anti-tumour efficiency of active substances isolated from A. elata. An in vitro experiment has revealed that processing of cell culture of cancer cells (human kidney cancer cell lines GRC-1 and 786-O) with different doses of araloside A significantly reduced their vitality and increased the number of Tunnel-positive cancer cells in the processed cell culture (Yu, 2011). Against tumour cells of humans (A549), the substances isolated from an alcohol extract of leaves of $A$. elata also exerted cytotoxicity (Kuang et al., 2013).

$\mathrm{Li}$ et al. (2019) have determined anti-cancer activity and pharmaceutical safety of alcohol extract from leaves of $A$. elata. The preparation has demonstrated high cytotoxicity for different lines of tumour cells in vitro, and also anti-tumour activity in vivo on mice with mammary gland cancer. The extract significantly downregulated the growth of tumour and induced apaptosis of MCF-7 cells. In that experiment, also the safety of the Aralia preparation for CNS and cardio-vascular system of mice and dogs was studied. The mice with mammary gland cancer, which were treated using the extract from leaves of $A$. elata, were observed to have no changes in the behaviour, moving activity and coordination of movement. There were no changes in the cardiovascular system in dogs. Frequency of heartbeat, parameters of electrocardiogram (interval of PR, interval of PR, duration of $\mathrm{P}$ and $\mathrm{QRS}$ peaks), frequency of breathing, respiratory volume, temperature of the body and arterial pressure showed no significant differences between the experimental and control groups (Li et al., 2019).

Use of medicinal plants can be important for prevention of human diseases induced by intestinal microorganisms: over change in their number, composition of communities and production of potentially harmful metabolites (Ahn et al., 1994). Extract from roots of Aralia has antifungal effect against Pyricularia grisea and antibacterial activity towards gram-positive bacilli.

Peroral treatment of women with non-diabetic obesity, who received low-calorie diet, with a preparation which contained extracts from A. elata and Engelhardia chrysolepis (Juglandaceae) led to decrease in the total body weight and mass of fat, reduction of perilipin in adipocytes and content of triglycerides in blood plasma, stimulation of activity of hormone-sensitive lipase (Abidov et al., 2006). We should note the influence of high-fat diet on development of obesity, hepatic steatosis, type 2 diabetes, and also pathogenesis of dysbiotic syndrome (Cani et al., 2007; Cho et al., 2009).

According to the classification of toxicity, the substance with $\mathrm{LD}_{50}$ equaling 0.5 to $5.0 \mathrm{~g} / \mathrm{kg}$ perorally is low-toxic (Loomis \& Hayes, 1996). Surveys by Li et al. (2015) have revealed that for extract of Aralia this parameter equals $3.16 \mathrm{~g} / \mathrm{kg}$ for females and $5.84 \mathrm{~g} / \mathrm{kg}$ for males. In experiments aimed at determination of toxicity of preparations of Aralia the maximum tolerance of rats equaled $1.00 \mathrm{~g} / \mathrm{kg}$ for females and $2.15 \mathrm{~g} / \mathrm{kg}$ for males. Therefore, use of alcohol tincture of the plant in one way or the other will affect the growth and development of animals, especially following disorders in metabolism.

The objective of this study was to determine the general effect of different doses of alcohol tincture of roots of $A$. elata on the growth and development of young laboratory rats and their gut microbiota against the background of excessive fat content.

\section{Materials and methods}

This study was performed in correspondence to the principles described in the guidance on maintaining and using experimental animals, according to ethical norms formulated in the order No 3447-IV from 21.02.2006 "On protection of animals against cruel treatment" and approved by the local ethics committee of the Dnipro National AgrarianEconomic University (Dnipro, Ukraine). The young of non pedigree laboratory male rats weighing $50 \pm 10 \mathrm{~g}$ were maintained in normal conditions: 12-day cycle "day - night", free access to food and water (Lieshchova et al., 2019). Diet of all animals had excessive fat content (3600 kcal $/ \mathrm{kg}$ ) due to addition of sunflower oil (Table 1). 
Table 1

Diet of laboratory animals

\begin{tabular}{lc}
\hline Characteristic of diet, unit of measurement & Value of characteristic \\
\hline Metabolic energy, kcal/kg & $3,600.0$ \\
Dry matter, \% & 82.0 \\
Crude protein, \% & 22.3 \\
Crude cellulose, \% & 7.2 \\
Fat, \% & 13.5 \\
Carbohydrate, \% & 39.7 \\
Insoluble ash in HCl, \% & 0.9 \\
\multicolumn{1}{c}{ Other ingredients } & \\
Corn, \% & 33.0 \\
Full-fat soybean, \% & 39.0 \\
Sunflower seed meal, \% & 7.0 \\
Wheat middling, \% & 1.5 \\
Alfalfa meal, \% & 3.0 \\
Meat bone meal, \% & 2.0 \\
Molasses, \% & 1.0 \\
Vegetable oil, \% & 10.0 \\
Limestone, \% & 2.0 \\
Dicalcium phosphate, \% & 1.0 \\
NaCl, \% & 0.45 \\
Vitamin-mineral premixes, \% & 0.25 \\
Ca, \% & 1.20 \\
P, \% & 0.60 \\
\hline
\end{tabular}

Over the recent years, A. elata, as a valuable medical introducent, has been broadly used in botanical gardens of Ukraine (Burda \& Koniakin, 2019). We prepared alcoholic tincture using roots of the plant (34 year old roots were used), collected in the Botanical Garden of Oles Honchar Dnipro National University (Khromykh et al., 2018). The roots were cut into pieces of 4-5 cm length, rinsed in cold water, dried during two months to stable mass in the room temperature out of direct sunlight, fragmented using secateurs to $2-3 \mathrm{~mm}$ pieces, left to dissolve for 20 days in the temperature of $20^{\circ} \mathrm{C}$ in $70 \%$ ethyl alcohol in the ratio (by mass) of 1 part of dry roots to 5 parts of ethyl alcohol, the obtained tincture was filtrated, achieving its 10\% concentration using $70 \%$ ethyl alcohol.

Four groups of animals were formed with 7 animals in each one: the first group had free access to clean water, the second group - free access to $0.1 \%$ ethanol, the third group - to $0.1 \%$ ethanolic tincture of A. elata, the fourth group - to $0.01 \%$ ethanolic tincture of $A$. elata. The experiment lasted for 35 days (Table 2).

During the study, the animals were recorded as having changes in the body weight, amount of water and fodder consumed. After the experiment, the animals were subjected to euthanasia by drawing blood from the heart under narcosis $(80 \mathrm{mg} / \mathrm{kg}$ of ketamine and $12 \mathrm{mg} / \mathrm{kg}$ of xylazine, intraperitoneally). After dissection, we visually evaluated the condition of the internal organs (heart, liver, thymus, spleen, stomach, thin and large intestines, kidneys, testicles, breastbone) for presence of pathological changes, weighed on scales with accuracy to $1 \mathrm{mg}$ with following determination of index of the mass of the organs.

Blood samples taken during euthanasia were used for biochemical morphological surveys. Biochemical parameters were determined using an automatic analyzer Miura 200 (Italy) and a set of reagents High Technology (USA), PZ Cormay S.A. (Poland) and Spinreact S.A. (Spain). Total protein was determined using the biuret method; globulins and protein coefficient - calculational method; albumins - by reaction with Bromocresol green, activity of aspartate aminotransferase (AST) and alanine aminotransferase (ALT) - by kinetic method based on the optical test of Warburg; alkaline phosphatase - enzymic method with n-nitrophenilphosphate; glucose - glucose-oxidase method. Number of erythrocytes and leukocytes in stabilized blood of the rats was determined using an automatic hematologic analyzer BC-2800Vet and Mindray. For the leukogram, blood smears were prepared using the Pappenheim method and stained with Giemsa stain.

Table 2

Characteristic of experimental groups of male rats

\begin{tabular}{|c|c|c|c|c|c|c|c|}
\hline Group & Feeding & Watering & $\begin{array}{c}\text { Average } \\
\text { amount of } \\
\text { ethanol } \\
\text { drunk by } \\
\text { one animal, } \\
\text { mg/day }\end{array}$ & $\begin{array}{l}\text { Average amount } \\
\text { of ethanol drunk } \\
\text { by one animal, } \\
\mathrm{mg} / \mathrm{kg} \text { of body } \\
\text { weight per day }\end{array}$ & $\begin{array}{c}\text { Average amount } \\
\text { of dry substances } \\
\text { extracted from } \\
\text { A. elata, consumed } \\
\text { by one animal, } \\
\text { mg/day }\end{array}$ & $\begin{array}{l}\text { Average amount of } \\
\text { dry substances ex- } \\
\text { tracted from } A \text {. elata, } \\
\text { consumed by one } \\
\text { animal, mg/kg of } \\
\text { body weight per day }\end{array}$ & $\begin{array}{l}\text { Average amount } \\
\text { of water in the } \\
\text { feeding mixture, } \\
\text { drunk by one } \\
\text { animal, g/day }\end{array}$ \\
\hline Control, $\mathrm{H}_{2} \mathrm{O}$ & $\begin{array}{l}\text { Free access to } \\
\text { fodder with exces- } \\
\text { sive content of fat }\end{array}$ & Free access to clean water & 0.0 & 0.0 & 0.00 & 0.00 & 25.2 \\
\hline $\begin{array}{l}\text { Control, } 0.1 \% \\
\text { ethanol }\end{array}$ & -" - & $\begin{array}{l}\text { Free access to } 0.1 \% \text { ethanol instead } \\
\text { of water }\end{array}$ & 26.8 & 258.1 & 0.00 & 0.00 & 26.8 \\
\hline $\begin{array}{l}0.01 \% \text { ethanolic } \\
\text { tincture of } A \text {. elata }\end{array}$ & $-“$ & $\begin{array}{l}\text { Free access to ethanolic tincture of } \\
\text { A. elata }(0.01 \%) \text { instead of water }\end{array}$ & 2.7 & 26.5 & 0.27 & 2.60 & 27.5 \\
\hline $\begin{array}{l}0.1 \% \text { ethanolic } \\
\text { tincture of } A \text {. elata }\end{array}$ & -“"- & $\begin{array}{l}\text { Free access to ethanolic tincture of } \\
\text { A. elata }(0.1 \%) \text { instead of water }\end{array}$ & 22.0 & 243.0 & 2.41 & 23.21 & 24.4 \\
\hline
\end{tabular}

In compliance with asepsis rules, the content of the rats' intestine was extracted from the rectum, directly after the animals were killed. For the study, $1 \mathrm{~g}$ of feces were stirred in a mortar with $9 \mathrm{~mL}$ of sterile physiologic solution $\left(10^{-1}\right.$ concentration) and then 8 serial ten-time dilutions were performed to obtain concentration of $10^{-9} \mathrm{~g}$ of feces per $1 \mathrm{~mL}$ of solution. These dilutions were inoculated to elective growth media and incubated in a thermostat at the temperature of $37^{\circ} \mathrm{C}$. The estimation was made after $24-72 \mathrm{~h}$, determining colony-forming units per gram of excrement (CFU/g) by counting the grown colonies.

For identifying and differentiating colonies, we studied morphological features, tinctorial, cultural and enzymic properties of microorganisms. By bacterioscopy of the stained smears, using generally accepted methods, we conducted visual confirmation of the studied microorganisms, and with mycological surveys - identified species of fungi.

The data were analyzed using Statistica 8.0 program (StatSoft Inc., USA). The tables demonstrate the results as $\mathrm{x} \pm \mathrm{SD}(\mathrm{x} \pm$ standard deviation). Differences between the values of the control and experimental groups were determined using the Tukey test (with consideration of Boniferroni's correction), where the differences were considered significant at $\mathrm{P}<0.05$.

\section{Results}

Over the 35-day experiment the animals increased their body weight from $54.7 \pm 10.8$ to $152.8 \pm 11.5 \mathrm{~g}$, that is an individual rat increased its body weight on average by $98.1 \mathrm{~g}$ - almost by three times. In the conditions of excessive content of fats in the food, the impact of alcohol reliably slowed the growth of rats (to the level of $78.4 \%$ of the control group). Replacing solution of ethyl alcohol with $0.01 \%$ or $0.1 \%$ tincture of $A$. elata caused no significant changes compared with the group of animals which consumed solution of ethyl alcohol (Table 3). Consumption of liquid in all four groups of animals significantly did not differ, changing on average in the range of 25.7-29.1 g per animal per day.

While having excessive content of fat in their food and consuming alcohol, the rats had a reliable decrease in the weight of the heart (to $77.8 \%$ of the values of the control group, Table 4). It is interesting that addition of equivalent amount of Aralia tincture instead of alcohol reduced notability of changes in the heart of animals. Consumption of $0.1 \%$ of solution of alcohol instead of drinking water against the background of excessive calorie content in the diet caused decrease in relative mass of the liver to $75.5 \%$ of the same value in the animals of the control group. Replacing 
ethyl alcohol with an equivalent amount of alcohol tincture of Aralia caused reliable increase (by 21.0\% compared with the control group) of relative mass of the liver. Relative mass of the lungs decreased during consumption of both ethyl alcohol and alcohol tincture of different concentration. Relative mass of the breastbone and the spleen in different variants of the experiments did not significantly change (Table 4).

Table 3

Change in the body weight and fodder consumption of young male rats under the impact of addition of ethanolic tincture of $A$. elata to their ration ( $\mathrm{x} \pm \mathrm{SD}, \mathrm{n}=7$, duration of experiment -35 days)

\begin{tabular}{|c|c|c|c|c|c|c|c|}
\hline Parameter & Control, $\mathrm{H}_{2} \mathrm{O}$ & $\begin{array}{c}\text { Control, } \\
0.1 \% \text { ethanol }\end{array}$ & $\begin{array}{c}\text { Control } \\
\text { (0.1\% ethanol) } \\
\text { compared to the } \\
\text { control }\left(\mathrm{H}_{2} \mathrm{O}\right), \%\end{array}$ & $\begin{array}{l}\text { Ethanolic tincture } \\
\text { of } A \text {. elata, } 0.01 \%\end{array}$ & $\begin{array}{l}\text { Ethanolic tincture } \\
\text { of } A \text {. elata }(0.01 \%) \\
\text { compared to the } \\
\text { control }\left(\mathrm{H}_{2} \mathrm{O}\right), \%\end{array}$ & $\begin{array}{l}\text { Ethanolic tincture } \\
\text { of } A \text {. elata, } 0.1 \%\end{array}$ & $\begin{array}{l}\text { Ethanolic tincture } \\
\text { of } \text { A. elata }(0.1 \%) \\
\text { compared to the } \\
\text { control }\left(\mathrm{H}_{2} \mathrm{O}\right), \%\end{array}$ \\
\hline Change in body weight, g/day & $3.29 \pm 0.07^{\mathrm{a}}$ & $2.58 \pm 0.21^{\mathrm{b}}$ & 78.4 & $2.64 \pm 0.13^{\mathrm{b}}$ & 80.3 & $2.90 \pm 0.20^{b}$ & 88.3 \\
\hline $\begin{array}{l}\text { Consumption of liquid } \\
\text { by animals, g/day }\end{array}$ & 26.7 & 28.3 & 106.0 & 29.1 & 109.0 & 25.7 & 96.1 \\
\hline
\end{tabular}

Note: different letters indicate values which reliably differed one from another within one line of the table according to the results of comparison using the Tukey test with Bonferroni correction.

Table 4

Change in relative mass of the organs $(\%)$ of male rats under the influence of addition to their ration of ethanolic tincture of $A$. elata ( $\mathrm{x} \pm \mathrm{SD}, \mathrm{n}=7$, duration of experiment -35 days)

\begin{tabular}{|c|c|c|c|c|c|c|c|}
\hline Organ & Control, $\mathrm{H}_{2} \mathrm{O}$ & $\begin{array}{c}\text { Control, } \\
0.1 \% \text { ethanol }\end{array}$ & $\begin{array}{c}\text { Control } \\
\text { (0.1\% ethanol) } \\
\text { compared to the } \\
\text { control }\left(\mathrm{H}_{2} \mathrm{O}\right), \%\end{array}$ & $\begin{array}{l}\text { Ethanolic tincture } \\
\text { of } A \text {. elata, } 0.01 \%\end{array}$ & $\begin{array}{l}\text { Ethanolic tincture } \\
\text { of } A \text {. elata }(0.01 \%) \\
\text { compared to the } \\
\text { control }\left(\mathrm{H}_{2} \mathrm{O}\right), \%\end{array}$ & $\begin{array}{l}\text { Ethanolic tincture } \\
\text { of } A \text {. elata, } 0.1 \%\end{array}$ & $\begin{array}{l}\text { Ethanolic tincture } \\
\text { of } \text { A. elata }(0.1 \%) \\
\text { compared to the } \\
\text { control }\left(\mathrm{H}_{2} \mathrm{O}\right), \%\end{array}$ \\
\hline Heart & $0.519 \pm 0.066^{\mathrm{a}}$ & $0.404 \pm 0.029^{b}$ & 77.8 & $0.417 \pm 0.041^{b}$ & 80.3 & $0.492 \pm 0.056^{\mathrm{ab}}$ & 94.8 \\
\hline Liver & $5.77 \pm 0.46^{\mathrm{a}}$ & $4.35 \pm 0.43^{\mathrm{b}}$ & 75.5 & $4.78 \pm 0.68^{\mathrm{b}}$ & 83.0 & $6.98 \pm 0.56^{\mathrm{c}}$ & 121.0 \\
\hline Lungs & $1.073 \pm 0.053^{\mathrm{a}}$ & $0.720 \pm 0.183^{b}$ & 67.1 & $0.869 \pm 0.041^{b}$ & 81.0 & $0.756 \pm 0.164^{b}$ & 70.5 \\
\hline Breast bone & $1.45 \pm 0.16^{\mathrm{a}}$ & $1.61 \pm 0.19^{\mathrm{a}}$ & 110.4 & $1.60 \pm 0.24^{\mathrm{a}}$ & 109.9 & $1.56 \pm 0.28^{\mathrm{a}}$ & 107.4 \\
\hline Thymus & $0.560 \pm 0.043^{\mathrm{a}}$ & $0.437 \pm 0.287^{\mathrm{ab}}$ & 78.0 & $0.305 \pm 0.023^{b}$ & 54.5 & $0.217 \pm 0.050^{c}$ & 38.7 \\
\hline Spleen & $0.442 \pm 0.033^{\mathrm{a}}$ & $0.422 \pm 0.036^{\mathrm{a}}$ & 95.5 & $0.477 \pm 0.193^{\mathrm{a}}$ & 107.9 & $0.407 \pm 0.051^{\mathrm{a}}$ & 92.1 \\
\hline Stomach & $0.790 \pm 0.106^{\mathrm{a}}$ & $0.706 \pm 0.091^{\mathrm{a}}$ & 89.3 & $0.814 \pm 0.082^{\mathrm{a}}$ & 103.0 & $0.969 \pm 0.107^{\mathrm{ab}}$ & 122.7 \\
\hline Small intestine & $6.65 \pm 0.45^{\mathrm{a}}$ & $5.14 \pm 0.21^{\mathrm{b}}$ & 77.3 & $6.45 \pm 0.87^{\mathrm{a}}$ & 97.1 & $6.57 \pm 0.85^{\mathrm{a}}$ & 98.9 \\
\hline Colon & $1.82 \pm 0.13^{\mathrm{a}}$ & $1.57 \pm 0.05^{\mathrm{b}}$ & 86.0 & $1.37 \pm 0.22^{\mathrm{b}}$ & 75.2 & $1.72 \pm 0.18^{\mathrm{ab}}$ & 94.5 \\
\hline Right kidney & $0.375 \pm 0.048^{\mathrm{a}}$ & $0.399 \pm 0.035^{\mathrm{a}}$ & 106.3 & $0.416 \pm 0.024^{\mathrm{a}}$ & 111.0 & $0.447 \pm 0.038^{\mathrm{a}}$ & 119.1 \\
\hline Left kidney & $0.398 \pm 0.053^{\mathrm{a}}$ & $0.374 \pm 0.018^{\mathrm{a}}$ & 93.9 & $0.428 \pm 0.036^{\mathrm{a}}$ & 107.6 & $0.460 \pm 0.042^{\mathrm{a}}$ & 115.6 \\
\hline Testis & $0.651 \pm 0.050^{\mathrm{a}}$ & $0.705 \pm 0.050^{\mathrm{a}}$ & 108.4 & $0.742 \pm 0.115^{\mathrm{a}}$ & 114.0 & $0.774 \pm 0.191^{\mathrm{a}}$ & 118.9 \\
\hline
\end{tabular}

Note: see Table 3.

A significant decrease was noted in the relative mass of the thymus following excessive content of fat in food and while consuming Aralia tincture: to $54.5 \%$ and $38.7 \%$ of the values of the control group for $0.01 \%$ and $0.1 \%$ Aralia tinctures respectively (Table 4 ).

Consumption of $0.1 \%$ tincture of Aralia instead of water, against the background of excessive content of fats in food, resulted in increase in relative mass of the stomach of rats by $22.7 \%$. Increase by $8.5 \%$ and $21.6 \%$ in relative mass of the thin and large intestines occurred while consuming tincture of Aralia, compared with the group which consumed equivalent amount of alcohol. Consumption of tincture of Aralia led to an unreliable increase in the relative mass of the kidneys (by $15.6 \%$ and $19.1 \%$ for the left and right kidneys respectively). Also, at the level of tendency (unreliably), an increase was seen in relative mass of the testicles: by $19.8 \%$ compared with the control group of rats (Table 4 ).

Consumption of $0.1 \%$ of ethanol instead of water resulted in a reliable increase by $26.9 \%$ in concentration of protein in blood, and replacement of ethanol with alcohol tincture of Aralia contributed to restoration of the concentration of protein in the blood to the normal level (Table 5). Similar changes were characteristic for concentration of albumins. Consuming ethyl alcohol following excessive consumption of fats caused reliable increase by $34.4 \%$ in concentration of globulins in the blood of rats, and with alcohol tincture of Aralia made this effect was less notable. Protein coefficient reliably decreased by $19.2 \%$ compared with the control group with consumption of $0.1 \%$ tincture of Aralia. Ethyl alcohol increased the content of creatinine in blood of animals by $30.9 \%$, and Aralia tincture made this less notable. Consumption of alcohol reduced activity of asparatate aminotransferase and alanine aminotransferase to $65.0 \%$ and $72.3 \%$ of the values of the control group, and tincture of Aralia restored the values of activity of these enzymes to the levels of the control group. The De Ritis ratio and concentration of total bilirubin in blood in all four groups of animals reliably did not differ. Activity of alkaline phosphate reached minimum values during consumption of $0.1 \%$ ethanolic tincture of $A$. elata, equaling $44.2 \%$ compared to the control.
Concentration of glucose in the blood of the rats fell to $85.6 \%$ of the level of the control group during consumption of solution of ethyl alcohol instead of water and to $91.6 \%$ of the control during consumption of $0.1 \%$ ethanolic tincture of $A$. elata (Table 5 ).

While drinking tincture of Aralia the concentration of calcium in the blood of the animals had a tendency towards growth (by 9.9-10.6\%), and non-organic phosphorus reliably fell (to $67.5-75.0 \%$ of the values of the control group). Ratio of $\mathrm{Ca} / \mathrm{P}$ during consumption of tincture of $A$. elata increased by $45.3 \%$ and $67.4 \%$ for the groups of animals which drank $0.01 \%$ and $0.1 \%$ ethanolic tincture of $A$. elata respectively (Table 5).

Apart from this, a strong decrease should be mentioned for the concentration of cholesterol to the level of $58.5 \%$ of the concentration of the control group during intake of $0.1 \%$ ethanolic tincture of $A$. elata (Table 5).

Drinking $0.1 \%$ Aralia tinicture instead of water increased the concentration of hemoglobin in the blood of rats by $10.8 \%$ (Table 6 ). Similar changes were observed also for hematocrit (increase by $12.5 \%$ ) and the amount of erythrocytes (increase by $6.9 \%$ ). No reliable changes were seen in the erythrocyte sedimentation rate, concentration of thrombocytes, eosinophiles and lymphocytes in the blood of animals in all the variants of the experiment. Concentration of monocytes in the rats did not decrease under the impact of alcohol compared with the control group of animals which consumed different concentrations of ethanolic tincture of A. elata (Table 6). We should emphasize that drinking Aralia tincture doubles the percent of the content of band-form leukocytes (to $200.0 \%$ and $213.3 \%$ of the values of the control group, Table 6 ).

Analysis of the studies of microbial composition of feces of the examined animals which received alcohol tincture of roots of $A$. elata in concentrations of $0.1 \%$ and $0.01 \%$ following a high fat diet during the experiment revealed that the level of representatives of normal microbiota (Bifidobacterium spp., Lactobacillus spp., Proteus spp., Staphylococcus spp., Candida spp., and also some lactose-negative enterobacteria (Citrobacter genus) in the experimental groups was close to the control (Fig. 1-3). 
Table 5

Change in biochemical parameters of blood of males of rats under effect of addition

to their ration of ethanolic tincture of $A$. elata $(\mathrm{x} \pm \mathrm{SD}, \mathrm{n}=7$, duration of experiment -35 days $)$

\begin{tabular}{|c|c|c|c|c|c|c|c|}
\hline Parameters & Control, $\mathrm{H}_{2} \mathrm{O}$ & $\begin{array}{c}\text { Control, } \\
0.1 \% \text { ethanol }\end{array}$ & $\begin{array}{c}\text { Control } \\
\text { (0.1\% ethanol) } \\
\text { compared to the } \\
\text { control }\left(\mathrm{H}_{2} \mathrm{O}\right), \%\end{array}$ & $\begin{array}{c}\text { Ethanolic } \\
\text { tincture of } \\
\text { A. elata, } 0.01 \%\end{array}$ & $\begin{array}{l}\text { Ethanolic tincture } \\
\text { of } A \text {. elata }(0.01 \%) \\
\text { compared to the } \\
\text { control }\left(\mathrm{H}_{2} \mathrm{O}\right), \%\end{array}$ & $\begin{array}{c}\text { Ethanolic } \\
\text { tincture of } \\
\text { A. elata, } 0.1 \%\end{array}$ & $\begin{array}{l}\text { Ethanolic tincture } \\
\text { of } A \text {. elata }(0.1 \%) \\
\text { compared to the } \\
\text { control }\left(\mathrm{H}_{2} \mathrm{O}\right), \%\end{array}$ \\
\hline Total protein, $\mathrm{g} / \mathrm{L}$ & $69.7 \pm 4.2^{\mathrm{a}}$ & $88.4 \pm 2.2^{b}$ & 126.9 & $73.0 \pm 6.0^{\mathrm{a}}$ & 104.8 & $73.6 \pm 3.7^{\mathrm{a}}$ & 105.6 \\
\hline Albumins, $\mathrm{g} / \mathrm{L}$ & $43.3 \pm 3.9^{\mathrm{a}}$ & $53.0 \pm 2.0^{\mathrm{b}}$ & 122.3 & $42.8 \pm 2.1^{\mathrm{a}}$ & 98.8 & $42.0 \pm 1.3^{\mathrm{a}}$ & 96.9 \\
\hline Globulins, g/L & $26.3 \pm 0.5^{\mathrm{a}}$ & $35.4 \pm 2.4^{\mathrm{b}}$ & 134.4 & $30.2 \pm 4.2^{\mathrm{ab}}$ & 114.7 & $31.6 \pm 2.6^{\mathrm{ab}}$ & 120.0 \\
\hline Protein coefficient, $\mathrm{U}$ & $1.63 \pm 0.09^{\mathrm{a}}$ & $1.50 \pm 0.11^{\mathrm{a}}$ & 91.8 & $1.42 \pm 0.15^{\mathrm{ab}}$ & 86.9 & $1.32 \pm 0.07^{\mathrm{b}}$ & 80.8 \\
\hline Urea, $\mathrm{mmol} / \mathrm{L}$ & $6.10 \pm 0.22^{\mathrm{a}}$ & $6.12 \pm 1.07^{\mathrm{ab}}$ & 100.3 & $4.66 \pm 0.87^{b}$ & 76.4 & $6.28 \pm 0.98^{\mathrm{ab}}$ & 103.0 \\
\hline Uric acid, $\mathrm{mg} / 100 \mathrm{~g}$ & $11.4 \pm 0.4^{\mathrm{a}}$ & $11.5 \pm 1.6^{\mathrm{ab}}$ & 100.8 & $8.9 \pm 1.7^{\mathrm{b}}$ & 77.7 & $12.0 \pm 1.9^{\mathrm{ab}}$ & 105.3 \\
\hline Creatinine, $\mu \mathrm{mol} / \mathrm{L}$ & $64.3 \pm 3.9^{\mathrm{a}}$ & $84.2 \pm 3.2^{\mathrm{b}}$ & 130.9 & $71.2 \pm 7.1^{\mathrm{c}}$ & 110.7 & $71.2 \pm 5.8^{\mathrm{c}}$ & 110.7 \\
\hline AST, U/L & $216 \pm 29^{\mathrm{a}}$ & $140 \pm 39^{\mathrm{b}}$ & 65.0 & $231 \pm 30^{\mathrm{a}}$ & 106.9 & $231 \pm 19^{\mathrm{a}}$ & 107.1 \\
\hline ALT, U/L & $84.3 \pm 8.1^{\mathrm{a}}$ & $61.0 \pm 5.5^{\mathrm{b}}$ & 72.3 & $95.0 \pm 12.8^{\mathrm{a}}$ & 112.7 & $90.2 \pm 13.8^{\mathrm{a}}$ & 107.0 \\
\hline De Ritis ratio (AST/ALT), U & $2.57 \pm 0.25^{\mathrm{a}}$ & $2.34 \pm 0.74^{\mathrm{a}}$ & 91.2 & $2.26 \pm 0.43^{\mathrm{a}}$ & 88.1 & $2.66 \pm 0.46^{\mathrm{a}}$ & 103.6 \\
\hline Alkaline phosphatase, U/L & $1564 \pm 192^{\mathrm{a}}$ & $1057 \pm 85^{\mathrm{b}}$ & 67.6 & $1548 \pm 378^{\mathrm{a}}$ & 99.0 & $691 \pm 103^{c}$ & 44.2 \\
\hline Total bilirubin, $\mu \mathrm{mol} / \mathrm{L}$ & $5.90 \pm 0.33^{\mathrm{a}}$ & $5.30 \pm 0.62^{\mathrm{a}}$ & 89.8 & $5.80 \pm 0.41^{\mathrm{a}}$ & 98.3 & $4.96 \pm 1.10^{\mathrm{a}}$ & 84.1 \\
\hline Glucose, $\mathrm{mmol} / \mathrm{L}$ & $6.33 \pm 0.34^{\mathrm{a}}$ & $5.42 \pm 0.37^{\mathrm{b}}$ & 85.6 & $6.02 \pm 0.42^{\mathrm{ab}}$ & 95.1 & $5.80 \pm 0.76^{\mathrm{ab}}$ & 91.6 \\
\hline Total calcium, $\mathrm{mmol} / \mathrm{L}$ & $2.57 \pm 0.39^{\mathrm{a}}$ & $3.28 \pm 0.28^{b}$ & 127.8 & $2.82 \pm 0.19^{\mathrm{ab}}$ & 109.9 & $2.84 \pm 0.15^{\mathrm{ab}}$ & 110.6 \\
\hline Non-organic phosphorus, $\mathrm{mmol} / \mathrm{L}$ & $4.00 \pm 0.24^{\mathrm{a}}$ & $3.58 \pm 0.47^{\mathrm{ab}}$ & 89.5 & $3.00 \pm 0.18^{\mathrm{b}}$ & 75.0 & $2.70 \pm 0.28^{\mathrm{b}}$ & 67.5 \\
\hline Ratio of $\mathrm{Ca} / \mathrm{P}$ & $0.633 \pm 0.125^{\mathrm{a}}$ & $0.946 \pm 0.199^{\mathrm{ab}}$ & 149.4 & $0.920 \pm 0.075^{\mathrm{b}}$ & 145.3 & $1.060 \pm 0.120^{\mathrm{b}}$ & 167.4 \\
\hline Cholesterol, $\mathrm{mmol} / \mathrm{L}$ & $1.300 \pm 0.163^{\mathrm{a}}$ & $1.060 \pm 0.080^{\mathrm{ab}}$ & 81.5 & $1.140 \pm 0.196^{\mathrm{ab}}$ & 87.7 & $0.760 \pm 0.196^{\mathrm{b}}$ & 58.5 \\
\hline
\end{tabular}

Note: see Table 3.

\section{Table 6}

Change in general analysis of blood and leukogram of male rats under effect of addition to their ration of ethanolic tincture of $A$. elata $(\mathrm{x} \pm \mathrm{SD}, \mathrm{n}=7$, duration of experiment -35 days $)$

\begin{tabular}{|c|c|c|c|c|c|c|c|}
\hline Parameter & Control, $\mathrm{H}_{2} \mathrm{O}$ & $\begin{array}{c}\text { Control, } \\
0.1 \% \text { ethanol }\end{array}$ & $\begin{array}{c}\text { Control } \\
\text { (0.1\% ethanol) } \\
\text { compared to the } \\
\text { control }\left(\mathrm{H}_{2} \mathrm{O}\right), \%\end{array}$ & $\begin{array}{c}\text { Ethanolic } \\
\text { tincture of } \\
\text { A. elata, } 0.01 \%\end{array}$ & $\begin{array}{l}\text { Ethanolic tincture } \\
\text { of } A \text {. elata }(0.01 \%) \\
\text { compared to the } \\
\text { control }\left(\mathrm{H}_{2} \mathrm{O}\right), \%\end{array}$ & $\begin{array}{c}\text { Ethanolic } \\
\text { tincture of } \\
\text { A. elata, } 0.1 \%\end{array}$ & $\begin{array}{l}\text { Ethanolic tincture } \\
\text { of } \text { A. elata }(0.1 \%) \\
\text { compared to the } \\
\text { control }\left(\mathrm{H}_{2} \mathrm{O}\right), \%\end{array}$ \\
\hline Hemoglobin, $\mathrm{g} / \mathrm{L}$ & $123.3 \pm 7.7^{\mathrm{ab}}$ & $123.4 \pm 7.9^{\mathrm{ab}}$ & 100.1 & $115.4 \pm 10.3^{\mathrm{a}}$ & 93.6 & $136.6 \pm 7.6^{\mathrm{b}}$ & 110.8 \\
\hline Hematocrit, $\%$ & $39.7 \pm 0.2^{\mathrm{ab}}$ & $39.6 \pm 3.1^{\mathrm{ab}}$ & 99.9 & $36.8 \pm 3.0^{\mathrm{a}}$ & 92.7 & $44.6 \pm 3.6^{b}$ & 112.5 \\
\hline Erythrocytes, $10^{12} / \mathrm{L}$ & $7.57 \pm 0.21^{\mathrm{ab}}$ & $7.32 \pm 0.70^{\mathrm{ab}}$ & 96.7 & $6.62 \pm 0.72^{\mathrm{a}}$ & 87.5 & $8.09 \pm 0.67^{b}$ & 106.9 \\
\hline $\begin{array}{l}\text { erythrocyte sedimentation rate } \\
\text { (ESR), } \mathrm{mm} / \mathrm{h}\end{array}$ & $1.0 \pm 0.0^{\mathrm{a}}$ & $1.0 \pm 0.0^{\mathrm{a}}$ & 100.0 & $1.0 \pm 0.0^{\mathrm{a}}$ & 100.0 & $1.0 \pm 0.0^{\mathrm{a}}$ & 100.0 \\
\hline Thrombocytes, $10^{9} / \mathrm{L}$ & $358 \pm 44^{\mathrm{a}}$ & $409 \pm 66^{\mathrm{a}}$ & 114.4 & $323 \pm 41^{\mathrm{a}}$ & 90.2 & $349 \pm 98^{\mathrm{a}}$ & 97.6 \\
\hline Leukocytes, $10^{9} / \mathrm{L}$ & $9.6 \pm 0.6^{\mathrm{a}}$ & $10.7 \pm 2.5^{\mathrm{ab}}$ & 111.5 & $11.8 \pm 1.2^{\mathrm{b}}$ & 123.3 & $11.4 \pm 1.3^{\mathrm{ab}}$ & 118.8 \\
\hline \multicolumn{8}{|l|}{ Leukocytic formula } \\
\hline Eosinophils, \% & $1.0 \pm 0.0^{\mathrm{a}}$ & $0.7 \pm 0.5^{\mathrm{a}}$ & 66.7 & $1.0 \pm 0.0^{\mathrm{a}}$ & 100.0 & $1.0 \pm 0.0^{\mathrm{a}}$ & 100.0 \\
\hline \multicolumn{8}{|l|}{ Neutrophils, \%: } \\
\hline - young & $0^{\mathrm{a}}$ & $0^{\mathrm{a}}$ & - & $0^{\mathrm{a}}$ & - & $0^{\mathrm{a}}$ & - \\
\hline - band & $3.0 \pm 3.6^{\mathrm{ab}}$ & $3.2 \pm 1.2^{\mathrm{a}}$ & 106.7 & $6.4 \pm 2.4^{\mathrm{ab}}$ & 213.3 & $6.0 \pm 1.3^{\mathrm{b}}$ & 200.0 \\
\hline - with segmented nuclei & $18.3 \pm 3.9^{\mathrm{a}}$ & $23.2 \pm 1.7^{\mathrm{ab}}$ & 126.5 & $17.6 \pm 5.8^{\mathrm{a}}$ & 96.0 & $18.2 \pm 2.4^{\mathrm{a}}$ & 99.3 \\
\hline Lymphocytes, \% & $73.3 \pm 0.9^{\mathrm{a}}$ & $71.0 \pm 1.9^{\mathrm{a}}$ & 96.8 & $73.0 \pm 8.0^{\mathrm{a}}$ & 99.5 & $71.2 \pm 2.3^{\mathrm{a}}$ & 97.1 \\
\hline Monocytes, $\%$ & $4.25 \pm 1.26^{\mathrm{a}}$ & $1.33 \pm 0.52^{\mathrm{b}}$ & 31.4 & $2.00 \pm 0.89^{\mathrm{ab}}$ & 47.1 & $3.67 \pm 1.03^{\mathrm{a}}$ & 86.3 \\
\hline
\end{tabular}

Note: see Table 3 .

\section{Table 7}

Number of microorganisms (Lg CFU/gram of feces) in four groups of rats, to whose diet alchohol tincture of the roots of $A$. elata was added $(\mathrm{x} \pm \mathrm{SD}, \mathrm{n}=7$, duration of the experiment was 35 days)

\begin{tabular}{lccc}
\hline \multicolumn{1}{c}{ Gut microbiota } & $\begin{array}{c}\text { Control, } \\
\mathrm{H}_{2} \mathrm{O}\end{array}$ & $\begin{array}{c}\text { Control, } \\
0.1 \% \text { ethanol }\end{array}$ & $\begin{array}{c}\text { Ethanolic tincture } \\
\text { of } \text { A. elata, } 0.01 \%\end{array}$ \\
\hline Bifidobacterium spp. & $9.33 \pm 0.58$ & $9.40 \pm 0.89$ & $9.00 \pm 1.00$ \\
Lactobacillus spp. & $8.33 \pm 0.58$ & $8.40 \pm 0.55$ & $8.80 \pm 0.45$ \\
Escherichia coli typical $A$ elata, $0.1 \%$ & $8.80 \pm 0.84$ \\
Enterococcus spp. & $8.00 \pm 0.00$ & $5.36 \pm 3.03$ & $6.46 \pm 3.66$ \\
Proteus spp. & $7.33 \pm 0.55$ & $4.52 \pm 2.65$ & $4.39 \pm 2.50^{\#}$ \\
Enterobacter spp. & $3.03 \pm 0.50$ & $3.94 \pm 0.37$ & $3.25 \pm 1.82$ \\
Citrobacter spp. & $2.00 \pm 0.00$ & $0.80 \pm 1.10$ & $1.26 \pm 1.16$ \\
Klebsiella spp. & $1.43 \pm 1.25$ & $2.79 \pm 1.57$ & $1.27 \pm 1.74$ \\
Clostridium spp. & $0.00 \pm 0.00$ & $0.40 \pm 0.89$ & $0.00 \pm 0.00^{*}$ \\
Staphylococcus spp. & $1.33 \pm 1.15$ & $1.20 \pm 1.10$ & $0.40 \pm 0.89$ \\
Candida spp. & $3.53 \pm 0.68$ & $1.86 \pm 1.84$ & $3.17 \pm 0.74$ \\
\hline
\end{tabular}

Notes: $*-\mathrm{P}<0.05$ comparison with the groups where the liquid for the animals was ethanol, ${ }^{*}-\mathrm{P}<0.05$ compared with the groups where the liquid for the animals was water.

During the experiment, compared with the control, no reliable changes in the composition of the gut microbiota were seen in the group of rats which had alcohol introduced into their diet. Because alcohol can be one of the main factors affecting the composition of gut microbiota, we should note that adding alcohol tincture and ethanol to high-fat diet contributed to decrease in the number of typical E. coli (Table 7). However, this parameter was reliably higher (by one hundred times) after high concentrations were drunk $(0.1 \%)$ and by ten times after low concentrations of tincture of 
roots of $A$. elata were drunk $(0.01 \%)$, by contrast to presence of $E$. coli, detected in animals which had been given ethanol.

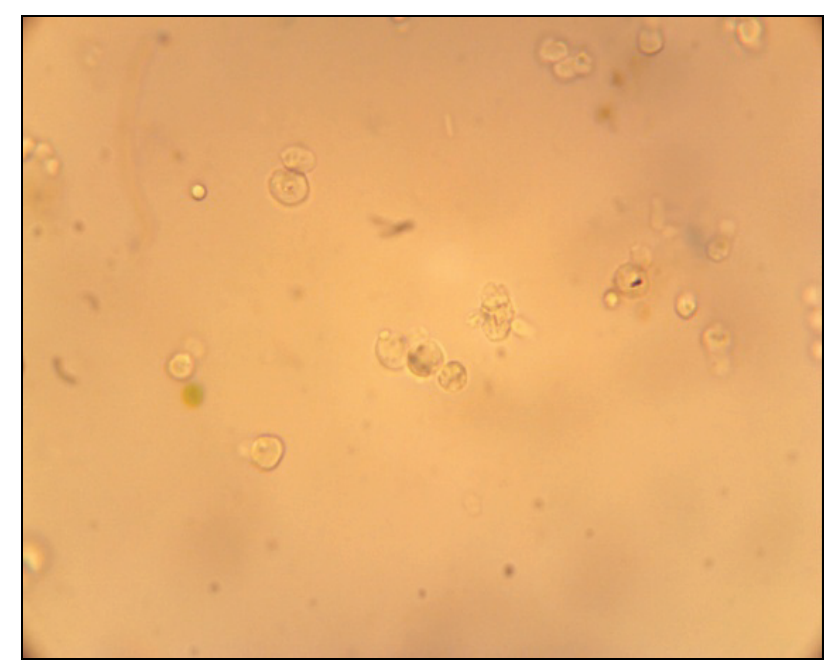

Fig. 1. Drops of neutral fat in the native preparations of feces of rats of the control group which drank water: bar $-10 \mu \mathrm{m}$

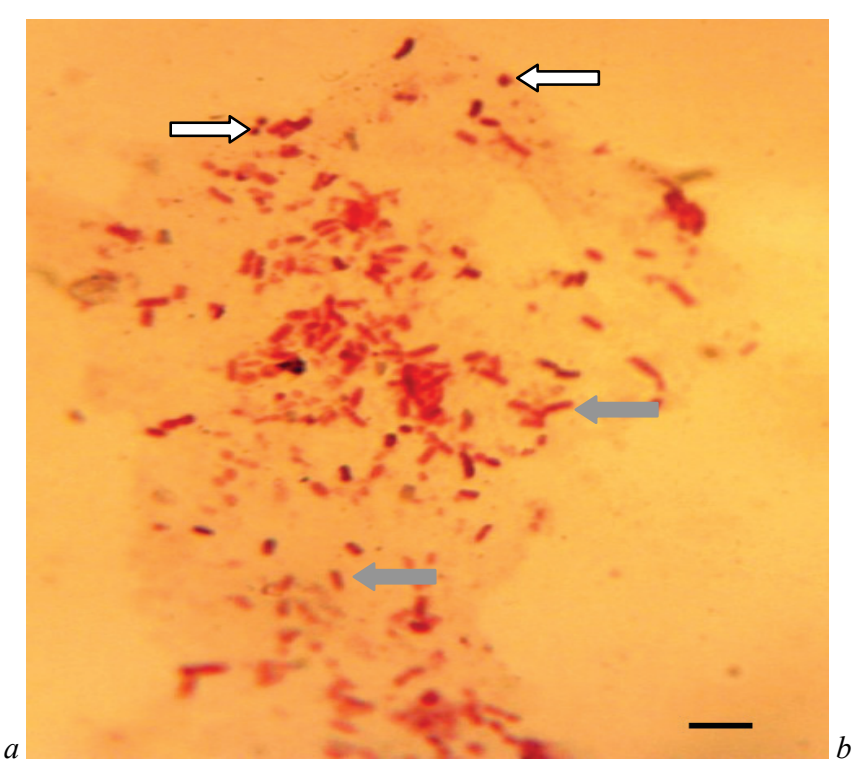

Fig. 2. Microscopic image of feces of rats of the control group, which received water: $a$ - Gramm staining, $b$-Zlatogorov staining, white arrows - spherical forms, grey arrows - rod-shaped bacterium, black arrow - spore-forming forms; bar $-5 \mu \mathrm{m}$

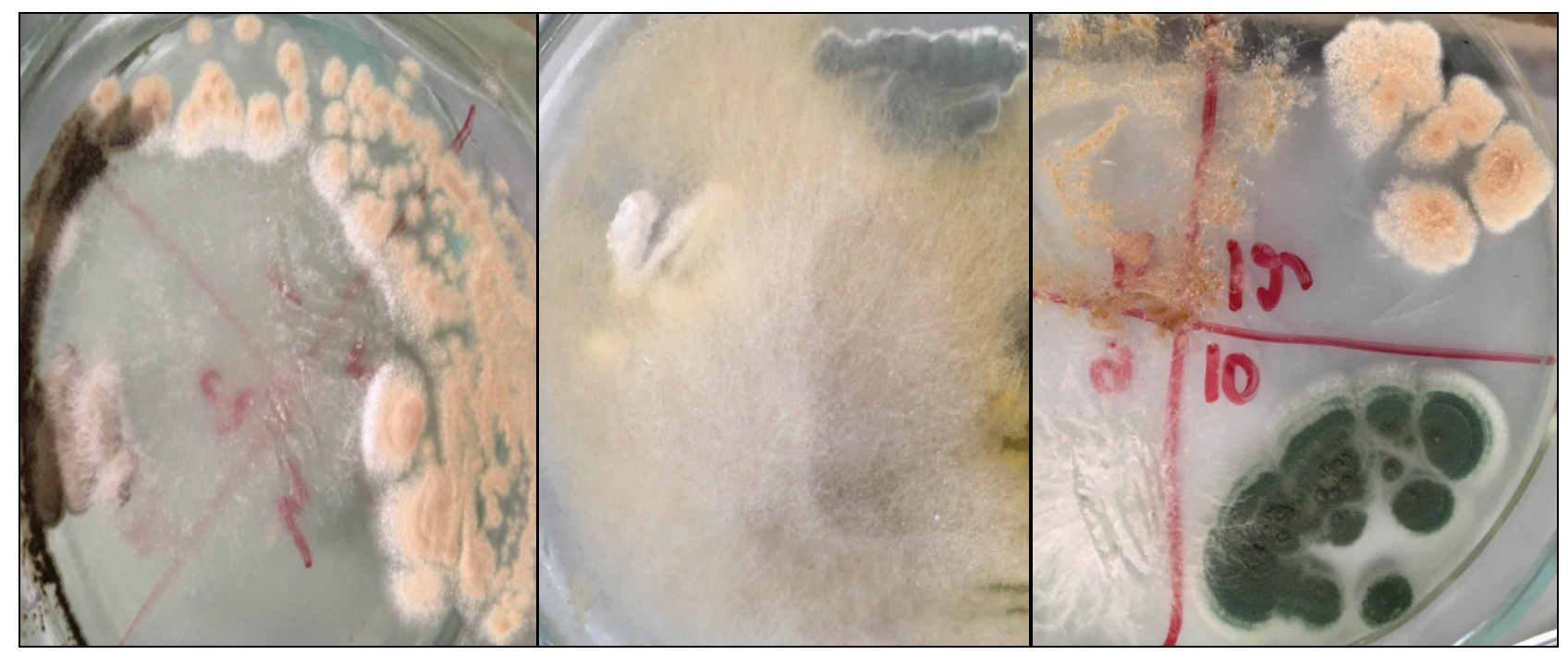

Fig. 3. Growth of different colonies of mold in Sabouraud agar, 5th day at $26^{\circ} \mathrm{C}$ : natural size 

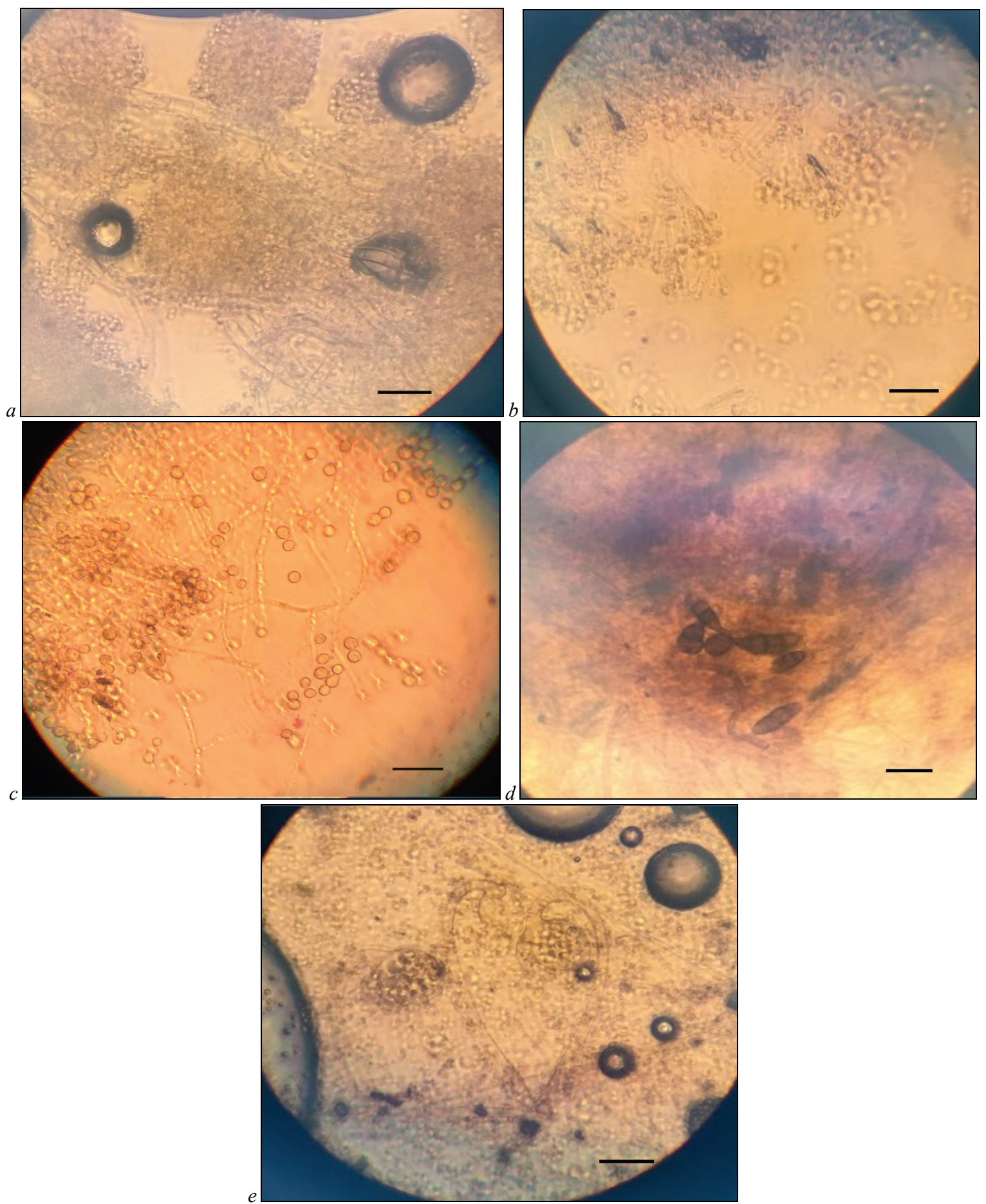

Fig. 4. Micromorphology of fungi: $a$ - final conidiophore heads with sterigmata and unfallen conidia of Aspergillus flavus; $b$ - sterigmata of Aspergillus niger, arranged in two layers; $c$ - aerial mycelium of Acremoniella atra, some conidiophores have rounded young conidia;

fallen oviform, colourless (young) and brown conidia are notable; $d$-conidia of Alternaria spp.: mature conidia with transverse and

longitudinal septa, round at the base, and pointed at the end, with a short conidiophore at the base; young conidia are elongated with transverse septa; $e$ - rounded sporanges of Mucor spp., empty and full with sporangiospores; bar - $10 \mu \mathrm{m}$

\section{Discussion}

In the experiment, against the background of excessive content of fat in the diet of rats, we observed no significant increase in the mass of animals. In the control, gain of body weight of animals did not exceed $3.29 \mathrm{~g} /$ day, and was much lower during consumption of alcohol and different doses of alcohol tincture of Aralia. Increase in the animals' body weight to a large extent depends on the content of carbohydrates rather than fat. The weight of the rats given a high fat diet in the experiment changed insignificantly compared with the control (usual diet), and addition of fructose to the diet led to reliable increase in the body weight already in the third week of the experiment compared both with the control group and animals which received excessive content of fat in the fodder (Ozkan \& Yakan, 2019). Study for subchronic toxicity of the tincture in the doses of 60,180 and $540 \mathrm{mg} / \mathrm{kg}$ on the rats during 12 weeks with the following 4-week period of recovery showed that the preparation caused no gross changes in consumption of fodder by animals. However, with consumption of high doses of the tincture, body weight of male rats increased slowly compared with the control during the period of recovery (Li et al., 2015). Therefore, reduction of tempi of growth of animals whose diet had high content of fats, in our opinion, to a larger degree depended on the alcohol. 
Mass of the organs is often used as a sensitive indicator for evaluating the toxic impact of different substances, including medical (Balogun et al., 2014; Varcholyak \& Gutyi, 2019). Relative mass of the organs of animals following the diet with excessive content of fat changed both under the influence of alcohol and alcohol tincture of Aralia. Relative mass of the heart was reliably lower in all the variants of the experiment, and most significantly differed from the control with consumption of pure $0.1 \%$ ethanol. The high-fat diet itself did not lead to changes in the relative mass of the heart of animals, it remained within reference values of the norm for the corresponding age group (Abrashova et al., 2013). Relative mass of the liver along with biochemical blood parameters are indicators which can characterize functional condition of the organism. Against the background of excess of fat in the diet, the animals were observed to have a reliably low index of liver mass, which can be explained by development of hepatic steatosis as a result of which lipid drops accumulate in hepatocytes and the organ becomes lighter. When ethanol and low concentrations of Aralia were added to the diet, the process exacerbated, and during use of $0.1 \%$ alcohol tincture, by contrast, the mass of the organ significantly increased compared both with the control and other variants of the experiment, which can indicate the hepatoprotective activity of the plant. On the model of hepactic steatosis, in oleic acid-induced HepG2 cells, Hwang et al. (2015) observed a general medical effect of the extract of $A$. eleta. The substances of this plant have been proved to reduce accumulation of lipids in the liver and significantly decrease the expression of genes with lipolytic activity, increase expression of genes with lipolytic activity in HepG2 cells, and also rapidly increase consumption of glucose (Hwang et al., 2015). The study by Luo et al. (2015) on laboratory rats has demonstrated that treatment of non-alcohol hepatic steatosis caused by excessive-fat diet using aralosides from roots of $A$. eleta in different doses $(75,150 \mathrm{mg} / \mathrm{kg}$ per day, intragastric) over 12 weeks led to decrease in activity of ALT and AST in the blood. Also, the animals were seen to have a decrease in the expression of protein and mRNA of anti-inflammatory cytokines (IL-6, MCP-1, TNF- $\alpha$ ), but concentration of total lipids in blood was constant. At the histological level, decrease in steatosis of hepatocytes was detected, and immunohistologically the aralosides were shown to regulate apoptosis and expression of proteins of inflammation, reducing phosphorylation of IREE-12, JNK, IkB and the subsequent activation of NF-kB p65 (Luo et al., 2015).

With use of alcohol tinctures of Aralia in different concentrations, and also when using ethanol, decrease in relative mass of the lungs was observed, with this organ showing normal parameters against the background of excess of fat in the diet. Relative mass of the spleen, kidneys and testicles was lower than the reference values in all groups of animals, and during the use of Aralia tincture the reduction was much less notable. Decreases in the mass of thymus (by 16\%), spleen (by 19\%) and adrenal glands (by 33\%) were observed in mice subjected to long $(18 \mathrm{~h})$ immobilizing stress during simultaneous injection of Aralia tincture $(0.1 \mathrm{mg} / \mathrm{kg}$, perorally, five times a day), confirming the anti-stress property of this preparation (Chernyak \& Titova, 2014).

Hematological and biochemical parameters are the main diagnostic criteria in clinical practice. Values of some hematological and biochemical markers indicate an unfavourable effect of the medicines on organs and systems (Young \& Friedman, 2001). Standard markers of normal function of the liver are biochemical blood parameters: AST, ALT, alkaline phosphatase, amount of albumins (Yu et al., 2012). The function of the kidneys is examined by such biochemical markers as creatinine, urea and the level of uric acid in the blood (Jia et al., 2014), whereas the functions of the heart are indicated by activity of creatinine kinase (Bakoma et al., 2013). Li et al. (2015) have determined that different doses of extract of $A$. elata have no effect on the system of the blood of rats. In our research, both high-fat diet and addition of ethanol and alcohol tinctures of Aralia led to changes in blood parameters. Against the background of excess of fat in the diet during use of ethanol, the animals were observed to have signs of dehydration and abnormal functioning of the liver and kidneys. When using alcoholic tinctures of Aralia these disorders were less notable. Compared with the control group, the animals of the experimental groups were observed to have notable hyperproteinemia and dysproteinemia, mostly due to hyper albumins against the background of hypoglobulemia. Decrease in the level of globulins can indicate immunosuppressive effect, and by this fact Li et al. (2015) explain the change in this parameter of rats' blood during intake of 60 , 180 and $540 \mathrm{mg} / \mathrm{kg}$ doses of extract of A. elata. In our experiment, in the experimental group of the animals, decrease in globulins was minimum, and with use of alcohol and alcohol tincture of A. elata reliably increased, but did not reach reference values of the healthy animals (Abrashova et al., 2013).

The immunosuppressive action of this preparation can be indicated also by condition of the main organ of the immune protection - thymus, the mass of which was reliably lower in the groups of animals that received $0.01 \%$ and $0.1 \%$ ethanolic tincture of $A$. elata. In the thymus, stem cells of the bone marrow transform into T-lymphocytes, undergoing antigen-independent proliferation and differentiation (Carrio \& Lopez, 2013). In determining chronic activity of the extract of Aralia on rats, a significant reduction of absolute and relative mass of the thymus was observed in the group of animals with high dose and only at the end of the treatment, but pathohistological analysis showed no changes (Li et al., 2015).

As is known, the same preparation, depending on dose, can have either therapeutic or toxic effect. Presumably, the effect on the immune system is one of the mechanisms of anti-tumour action of the extract of root of A. elata (Yu, 2011; Li et al., 2019).

The high-fat diet caused increase in the activity of the main hepatic enzymes (AST and ALT) compared with reference values for this age group of rats. However, consumption of alcohol reduced the activity of enzymes practically to the norm, and alcohol tinctures of Aralia in different concentrations intensified this process. By activity of enzymes in blood (alanine aminotransferase (ALT), gamma-glutamiltranspeptidase (GGT), serum alkaline phosphatase (SAP)), a hepatobiliar toxic effect of the extract of the root of Aralia in different doses $(0.16,1.50$ and $3.00 \mathrm{~g} / \mathrm{kg}$ ) was determined on swine. By the end of the experiment (60th day), regardless of the dose, the level of ALT and GGT significantly increased, which together with increase in the level of lymphocytes and polymorphonuclear neutrophils in the portal and periportal regions indicates subclinical hepatitis (Burgos et al., 1997).

The level of glucose in blood of the animals given a high-fat diet increased, and during use of Aralia tincture insignificantly reduced, but without reaching reference values (Abrashova et al., 2013). High hypoglycaemic activity of metabolites of A. elata was observed in the experiment for identifying tolerance to sacharose. At the same time, the rats were earlier perorally given oleic acid and oligoglycosides) $(100 \mathrm{mg} / \mathrm{kg})$, $30 \mathrm{~min}$ before being given glucose. These metabolites displayed high hypoglycaemic activity (Yoshikawa et al., 1993, 1996).

Qualitative and quantitative composition of gut microbiota and multicellular intestinal parasites can change depending on the compound of food, age, taking medical preparations (especially antibiotics), specifics of diet, diseases of infectious and non-infectious origin (Guinane \& Cotter, 2013; Boyko \& Brygadyrenko, 2016; Zazharskyi et al., 2019). The effect of a high-fat diet on development of obesity, hepatic steatosis, type 2 diabetes, and also pathogenesis of dysbiotic syndrome should also be mentioned (Cani et al., 2007; Cho et al., 2009). During the analysis of the results of microbiological study of feces of the animals in our experiment against the background of excess of fat in diet, we observed no serious changes in the composition of the normal gut microbiota (Bifidobacterium spp., Lactobacillus spp., Proteus spp., Staphylococcus spp., Candida spp.), and some lactose-generating bacteria (Citrobacter genus).

Wolf \& Lorenz (2012) have determined that in the process of obesity, the ratio of Firmicutes : Bacteroidetes increases, ending with overall increase in the population of Clostridium. The latter, acting as more effective carbohydrate metabolizers, extract more energy from food, allowing it to be used more efficiently. This additional energy, if not spent, will ultimately be stored as fat deposits (Wolf \& Lorenz, 2012). Similar results were obtained by the researchers who in experiments on animals determined that high-fat diet led to increased content of bacteria of the Firmicutes phylum and reduction of Bacteroidetes (Turnbaugh et al., 2008a). At the same time, data of the studies in humans vary. Some confirm this pattern (Ley et al., 2006; Turnbaugh et al., 2008b), whereas others found no significant difference (Duncan et al., 2008). Also, some surveys revealed increase in the number of Bacteroidetes in 
relation to Firmicutes in cases of obesity (Schwiertz et al., 2010). Hassan et al. (2018) determined that due to use of the high fat diet, the number of Bacteroidetes decreased and proportion of Firmicutes and Cyanobacteria increased in the cecum of the examined animals.

In our studies, in rats fed a high fat diet the consumption of $0.1 \%$ ethanol significantly did not change the amount of lumen gut microbiota compared with the animals which received water. Jakovlev et al. (2017) indicate that alcohol intoxication is accompanied by significant disorders in homeostasis, changes in protein, carbohydrate, lipid, mineral metabolisms, and an important role in these processes is played by dysbiotic shifts of the normal gut microbiota. In the experiments with rats subjected to alcohol intoxication over two months, disorders in the main symbiotic relations were seen, with increase in the transitory conditionally-pathogenic microbiota. A significant decrease in the amount of Escherichia of Clostridium in the intestinal content was observed. However, the content of enterococci did not change, and the number of Staphylococcus saprophyticus increased (Yakovleva \& Mikhaylova, 2012). Chronic endogenous alcohol intoxication in rats of young and mature experimental groups was accompanied by change in the balance in the biocenosis of the intestine towards pathogenic flora, and the most notable shift of the biocenosis towards pathogenic flora was seen in the animals of the adult age group (Knyshova et al., 2016).

Against the background of fat diet and use of ethanolic tincture of A. elata in our experiment, the amount of typical Escherichia coli was 100 times higher at high concentration $(0.1 \%)$ and 10 times higher at low concentration $(0.01 \%)$ of tincture of roots of $A$. elata, by contrast to animals that received ethanol. In the animals of the control group, a reliable 100 and 10,000 times decrease in the number of Enterococcus spp., and 100 times decrease in Enterobacter spp. was observed, compared with the animals that received no alcohol. We observed 1,000 times reduction of the number of microorganisms of Clostridium in the animals given $0.01 \%$ tincture, and $0.1 \%$ tincture of $A$. elata roots led to their elimination. After consumption of $A$. elata, the rats were observed to have no Klebsiella spp. Also we observed resistance against growth of pathogenic fungi in the intestinal content of animals which received ethanolic tincture of $A$. elata in high concentration (0.1\%). Similar antifungal action of the extract from Aralia continentalis $(125 \mathrm{mg} / \mathrm{L}$ and higher) was confirmed by Oh et al. (2016), when rice sheath blight was reduced by no less than $16 \%$.

\section{Conclusions}

Ethanolic tincture of $A$. elata has no effect on the intensity of growth of body weight of young rats against the background of excessive fat content in the fodder. Excessive fat diet leads mostly to disorder in hepatic function and development of steatosis, accompanied by reduction of its mass, increase in the activity of hepatic enzymes, dysproteinemia, increase in the level of bilirubin and decrease in urea level. Additional use of $0.1 \%$ ethanol caused disorder in function of kidneys decrease in their relative mass, signs of dehydration, increase in the creatinine level and total calcium in blood. Ethanolic tincture of $A$. elata alleviates the negative effect of excessive fat, leads to normalization in the indices of mass of the organs, less notable dysproteinemia, change in the level of creatinine, glucose, urea, cholysterol, bilirubin, and total calcium.

Ethanolic tincture of $A$. elata has a low immunosuppressive action, which manifests in decrease in the mass of thymus, especially with use of high dose of the tincture $(0.1 \%)$ and hypoglobulinemia, while total amount of lymphocytes in blood does not change.

Against the background of high-fat diet, ethanolic tincture of $A$. elata led to increase in the number of typical $E$. coli, decrease in Enterococcus spp. and Enterobacter spp., significant decrease and high concentrations $(0.1 \%)$ caused elimination of microorganisms of Clostridium and Klebsiella genera and various fungi.

\section{References}

Abidov, M. T., del Rio, M. J., Ramazanov, T. Z., Klimenov, A. L., Dzhamirze, S., \& Kalyuzhin, O. V. (2006). Effects of Aralia mandshurica and Engelhardtia chrysolepis extracts on some parameters of lipid metabolism in women with nondiabetic obesity. Bulletin of Experimental Biology and Medicine, 141(3), 343-346.

Abrashova, T. V., Gushhin, J. A., Kovaleva, M. A., Rybakova, A. V., Selezneva, A. I., Sokolova, A. P., \& Hod'ko, S. V. (2013). Fiziologicheskie, biohimicheskie i biometricheskie pokazateli normy eksperimental'nyh zhivotnyh [Physiological, biochemical and biometric indicators of the norm of experimental animals]. Lema, Saint Petersburg (in Russian).

Ahn, Y.-J., Kwon, J.-H., Chae, S.-H., Park, J.-H., \& Yoo, J.-Y. (1994). Growth-inhibitory responses of human intestinal bacteria to extracts of oriental medicinal plants. Microbial Ecology in Health and Disease, 7(5), 257-261.

Ahumada, F., Trincado, M. A., Arellano, J. A., Hancke, J., \& Wikman, G. (1991) Effect of certain adaptogenic plant extracts on drug-induced narcosis in female and male mice. Phytotherapy Research, 5(1), 29-31.

Bakoma, B., Berké, B., Eklu-Gadegbeku, K., Agbonon, A., Aklikokou, K., Gbeassor, M., Creppy, E. E., \& Moore, N. (2013). Acute and sub-chronic (28 days) oral toxicity evaluation of hydroethanolic extract of Bridelia ferruginea Benth root bark in male rodent animals. Food and Chemical Toxicology, 52, 176-179.

Balogun, S. O., da Silva, I. F., Colodel, E. M., de Oliveira, R. G., Ascêncio, S. D. \& Martins, D. T. O. (2014). Toxicological evaluation of hydroethanolic extract of Helicteres sacarolha A. St.- Hil. et al. Journal of Ethnopharmacology, 157, 285-291.

Boyko, A. A., \& Brygadyrenko, V. V. (2016). Influence of water infusion of medicinal plants on larvae of Strongyloides papillosus (Nematoda, Strongyloididae). Visnyk of Dnipropetrovsk University, Biology, Ecology, 24(2), 519-525.

Brekhman, I. I. (1963). Comparative data about pharmacological effects of ginseng, Eleutherococcus echinopanax and Aralia mandshurica. Materialy k izucheniju zhenshenja i drugih lekarstvennih rasteniy Dalnego Vostoka. Vol. 5. Primorskoe Knizhnoe Izdatelstvo, Vladivostok (in Russian).

Burda, R. I., \& Koniakin, S. N. (2019). The non-native woody species of the flora of Ukraine: Introduction, naturalization and invasion. Biosystems Diversity, 27(3), 276-290.

Burgos, R. A., Hancke, J. L., Cáceres, D. D., Wilkman, G., \& Fuenzalida, H. (1997). Hepatotoxic effect of Aralia mandshurica dried root extract in pigs. Phytotherapy Research, 11(1), 59-61.

Cani, P. D., Amar, J., Iglesias, M. A., Poggi, M., Knauf, C., Bastelica, D., Neyrinck, A. M., Fava, F., Tuohy, K. M., Chabo, C., Waget, A., Delmee, E., Cousin, B. Sulpice, T., Chamontin, B., Ferrieres, J., Tanti, J.-F., Gibson, G. R., Casteilla, L., Delzenne, N. M., Alessi, M. C., \& Burcelin, R. (2007). Metabolic endotoxemia initiates obesity and insulin resistance. Diabetes, 56(7), 1761-1772

Carrio, R., \& Lopez, D. M. (2013). Insights into thymic involution in tumorbearing mice. Immunologic Research, 57, 106-114.

Chernyak, D. M., \& Titova, M. S. (2014). Anti-stress effect of the far eastern plants. Pacific Medical Journal, 2, 28-30 (in Russian).

Cho, S. O., Ban, J. Y., Kim, J. Y., Jeong, H. Y., Lee, I. S., Song, K.-S., Bae, K. H. \& Seong, Y. H. (2009). Aralia cordata protects against amyloid $\beta$ protein (25-35)-induced neurotoxicity in cultured neurons and has antidementia activities in mice. Journal of Pharmacological Sciences, 111(1), 22-32.

Clement, J., \& Clement, E. (2015). The medicinal chemistry of genus Aralia. Current Topics in Medicinal Chemistry, 14(24), 2783-2801.

Duncan, S. H., Lobley, G. E., Holtrop, G., Ince, J., Johnstone, A. M., Louis, P., \& Flint, H. J. (2008). Human colonic microbiota associated with diet, obesity and weight loss. International Journal of Obesity, 32(11), 1720-1724.

Guinane, C. M., \& Cotter, P. D. (2013). Role of the gut microbiota in health and chronic gastrointestinal disease: Understanding a hidden metabolic organ. Therapeutic Advances in Gastroenterology, 6(4), 295-308.

Guo, M., Zhang, L., \& Liu, Z. (2009). Analysis of saponins from leaves of Aralia elata by liquid chromatography and multi-stage tandem mass spectrometry. Analytical Sciences, 25(6), 753-758.

Harin, S. A., Lunev, A. A., \& Bukatin, M. V. (2011). Ocenka funkcionalno-povedencheskoj aktivnosti krys na fone primenenija preparatov Aralia mandshurica [Assessment of functional-behavioral activity of rats on the background of the application of Aralia mandshurica drugs]. Successes in Modem Natural Sciences, 8, 75-75 (in Russian).

Hassan, A. M., Mancano, G., Kashofer, K., Fröhlich, E. E., Matak, A., Mayerhofer, R., Reichmann, F., Olivares, M., Neyrinck, A. M., Delzenne, N. M., Claus, S. P., \& Holzer, P. (2018). High-fat diet induces depression-like behaviour in mice associated with changes in microbiome, neuropeptide $\mathrm{Y}$, and brain metabolome. Nutritional Neuroscience, 2018, 1-17.

Hernandez, D. E., Hancke, J. L. \& Wikman, G. (1988). Evaluation of the antiulcer and antisecretory activity of extracts of Aralia elata root and Schizandra chinensis fruit in the rat. Journal of Ethnopharmacology, 23(1), 109-114.

Hwang, K.-A., Hwang, Y.-J., Kim, G. R., \& Choe, J.-S. (2015). Extracts from Aralia elata (Miq) Seem alleviate hepatosteatosis via improving hepatic insulin sensitivity. BMC Complementary and Alternative Medicine, 15, 347.

Jakovlev, A. T., Porojskij, S. V., Knyshova, L. P., \& Morkovin, E. I. (2017). Izmenenie mikrobioty kishechnika pri hronicheskoj alkogolizacii [A change in the intestinal microbiota in chronic alcoholization]. Samarskij Nauchnyj Vestnik, 6(3), 64-68 (in Russian). 
Jia, Z., Liu, M., Qu, Z., Zhang, Y., Yin, S., \& Shan, A. (2014). Toxic effects of zearalenone on oxidative stress, inflammatory cytokines, biochemical and pathological changes induced by this toxin in the kidney of pregnant rats. Environmental Toxicology and Pharmacology, 37(2), 580-591.

Jin, J. Y., Yang, H. K., Kim, J. M., Ko, M. S., Hong, H. J., Jin, Y. G., Kim, D. G., Kim, S. C., Lee, I. I., Hyon, M. K., Kang, S. C., Kim, J. H., \& Lee, Y. J. (2006). Four-week repeated oral toxicity study of the extract of Aralia elata in rats. Journal of Toxicology and Public Health, 22(4), 445-452.

Khromykh, N., Lykholat, Y., Shupranova, L., Kabar, A., Didur, O., Lykholat, T., \& Kulbachko, Y. (2018). Interspecific differences of antioxidant ability of introduced Chaenomeles species with respect to adaptation to the steppe zone conditions. Biosystems Diversity, 26(2), 132-138.

Knyshova, L. P., Porojskij, S. V., Jakovlev, A. T., \& Morkovin, E. I. (2016) Vlijanie eksperimental'noj hronicheskoj endogennoj alkogol'noj intoksikacii na mikrofloru kishechnika [The effect of experimental chronic endogenous alcohol intoxication on the intestinal microflora]. Vestnik Volgogradskogo Gosudarstvennogo Medicinskogo Universiteta, 60, 40-44 (in Russian).

Kuang, H.-X., Wang, Z.-B., Wang, Q.-H., Yang, B.-Y., Xiao, H.-B., Okada, Y., \& Okuyama, T. (2013). Triterpene glucosides from the leaves of Aralia elata and their cytotoxic activities. Chemistry and Biodiversity, 10(4), 703-710.

Lee, B., Hong, R., Lim, P., Cho, D., Yeom, M., Lee, S., Kang, K. S., Lee, S. C., Shim, I., Lee, H., \& Hahm, D.-H. (2019). The ethanolic extract of Aralia continentalis ameliorates cognitive deficits via modifications of BDNF expression and anti-inflammatory effects in a rat model of post-traumatic stress disorder. BMC Complementary and Alternative Medicine, 19, 11.

Ley, R. E., Turnbaugh, P. J., Klein, S., \& Gordon, J. I. (2006). Human gut microbes associated with obesity. Nature, 444(7122), 1022-1023.

Li, F., He, X., Niu, W., Feng, Y., Bian, J., \& Xiao, H. (2015). Acute and subchronic toxicity study of the ethanol extract from leaves of Aralia elata in rats. Journal of Ethnopharmacology, 175, 499-508.

Li, F., He, X., Niu, W., Feng, Y., Bian, J., Kuang, H., \& Xiao, H. (2016). Subchronic safety evaluation of the ethanol extract of Aralia elata leaves in Beagle dogs. Regulatory Toxicology and Pharmacology, 79, 1-11.

Li, F., Wang, W., \& Xiao, H. (2019). The evaluation of anti-breast cancer activity and safety pharmacology of the ethanol extract of Aralia elata Seem. leaves. Drug and Chemical Toxicology, 2019, 1-10.

Lieshchova, M. A., Brygadyrenko, V. V., Tishkina, N. M., Gavrilin, P. M., \& Bohomaz, A. A. (2019). Impact of polyvinyl chloride, polystyrene, and polyethylene on the organism of mice. Regulatory Mechanisms in Biosystems, 10(1), 50-55.

Loomis, T. A., \& Hayes, A. W. (1996). Numbers in toxicology. In: Loomis, T. A., \& Hayes, A. W. (Eds.). Loomis's essentials of toxicology. Academic Press. Pp. 17-32.

Luo, Y., Dong, X., Yu, Y., Sun, G., \& Sun, X. (2015). Total aralosides of Aralia elata (Miq) Seem (Tasaes) ameliorate nonalcoholic steatohepatitis by modulating IRE1 $\alpha$-mediated JNK and NF-кB pathways in ApoE mice. Journal of Ethnopharmacology, 163, 241-250.

Montiel-Ruiz, R. M., Roa-Coria, J. E., Patiño-Camacho, S. I., Flores-Murrieta, F. J., \& Déciga-Campos, M. (2012). Neuropharmacological and toxicity evaluations of ethanol extract from Rhodiola rosea. Drug Development Research, 73(2), 106-113.

Oh, T., Park, Y., Kim, C., Kim, Y., Kim, S., Kim, T., \& Jang, M. (2016). Antifungal activity against Aralia continentalis radix extract on rice sheath blight. Emirates Journal of Food and Agriculture, 28(11), 818.

Ozkan, H., \& Yakan, A. (2019). Dietary high calories from sunflower oil, sucrose and fructose sources alters lipogenic genes expression levels in liver and skeletal muscle in rats. Annals of Hepatology, 18(5), 715-724.

Panossian, A., Wikman, G., \& Wagner, H. (1999). Plant adaptogens III. Earlier and more recent aspects and concepts on their mode of action. Phytomedicine, 6(4), 287-300.

Panossian, A., Wikman, G., Kaur, P., \& Asea, A. (2012). Adaptogens stimulate neuropeptide $\mathrm{Y}$ and $\mathrm{Hsp} 72$ expression and release in neuroglia cells. Frontiers in Neuroscience, 6(6), 1-12.

Pivovarova, A. S., \& Lesiovskaya, E. E. (2003). Study of interaction of combinations of preparation from medicinal plants with tonic effects. Rastitelnye Resursy, 1, 94-101.

Pospelova, M. L., \& Barnaulov, O. D. (2000). The antihypoxant and antioxidant effects of medicinal plants as the basis for their use in destructive diseases of the brain. Human Physiology, 26(1), 86-91.

Saad, B., Azaizeh, H., Abu-Hijleh, G., \& Said, O. (2006). Safety of traditional arab herbal medicine. Evidence-Based Complementary and Alternative Medicine, 3(4), 433-439.

Saito, S., Ebashi, J., Sumita, S., Furumoto, T., Nagamura, Y., Nishida, K., \& Isiguro, I. (1993). Comparison of cytoprotective effects of saponins isolated from leaves of Aralia elata Seem. (Araliaceae) with synthesized bisdesmosides of oleanoic acid and hederagenin on carbon tetrachloride-induced hepatic injury. Chemical and Pharmaceutical Bulletin, 41(8), 1395-1401.

Schwiertz, A., Taras, D., Schäfer, K., Beijer, S., Bos, N. A., Donus, C., \& Hardt, P. D. (2010). Microbiota and SCFA in lean and overweight healthy subjects. Obesity, 18(1), 190-195

Shikov, A. N., Pozharitskaya, O. N., \& Makarov, V. G. (2016). Aralia elata var. mandshurica (Rupr. \& Maxim.) J. Wen: An overview of pharmacological studies. Phytomedicine, 23(12), 1409-1421.

Stjopin, S. G., Rodionova, R. A., Stjopina, M. A., \& Dikusar, E. A. (2019). Antiradikal'naja aktivnost' spirtovyh nastoek lekarstvennyh rastenij [Antiradical activity of alcoholic tinctures of medicinal plants]. Achievements of Fundamental Clinical Medicine and Pharmacy. VGMU, Vitebsk (in Russian).

Turnbaugh, P. J., Bäckhed, F., Fulton, L., \& Gordon, J. I. (2008a). Diet-induced obesity is linked to marked but reversible alterations in the mouse distal gut microbiome. Cell Host and Microbe, 3(4), 213-223.

Turnbaugh, P. J., Hamady, M., Yatsunenko, T., Cantarel, B. L., Duncan, A., Ley, R. E., Sogin, M. L., Jones, W. J., Roe, B. A., Affourtit, J. P., Egholm, M., Henrissat, B., Heath, A., Knight, R., \& Gordon, J. I. (2008b). A core gut microbiome in obese and lean twins. Nature, 457(7228), 480-484.

Turova, A. D. (1974). Lekarstvennye rastenija SSSR i ih primenenije [Medicinal plants of USSR and their applications]. Medicina, Moscow (in Russian).

Varcholyak, I. S., \& Gutyi, B. V. (2019). Determination of the chronic toxicity of preparation "Bendamin" on laboratory animals. Theoretical and Applied Veterinary Medicine, 7(2), 63-68

Wang, M., Xu, X., Xu, H., Wen, F., Zhang, X., Sun, H., Yao, F., Sun, G., \& Sun, X. (2014). Effect of the total saponins of Aralia elata (Miq) Seem on cardiac contractile function and intracellular calcium cycling regulation. Journal of Ethnopharmacology, 155(1), 240-247.

Wang, Q.-H., Zhang, J., Ma, X., Ye, X.-Y., Yang, B.-Y., Xia, Y.-G., \& Kuang, H.-X. (2011). A new triterpenoid saponin from the leaves of Aralia elata. Chinese Journal of Natural Medicines, 9(1), 17-21.

Wolf, K. J., \& Lorenz, R. G. (2012). Gut microbiota and obesity. Current Obesity Reports, 1(1), 1-8.

Yakovleva, L. M., \& Mikhaylova, L. A. (2012). The disturbance of microbiocenosis and the reabsorbtion of microelements in the colon of rats during alcoholic intoxication. Bulletin of the Chuvash University, 3, 541-543.

Yoshikawa, M., Harada, E., Matsuda, H., Murakami, T., Yamahara, J., \& Murakami, N. (1993). Elatosides A and B, potent inhibitors of ethanol absorption in rats from the bark of Aralia elata Seem.: The structure-activity relationships of oleanolic acid oligoglycosides. Chemical and Pharmaceutical Bulletin, 41(11), 2069-2071.

Yoshikawa, M., Murakami, T., Harada, E., Murakami, N., Yamahara, J., \& Matsuda, H. (1996). Bioactive saponins and glycosides. VI. Elatosides A and B, potent inhibitors of ethanol absorption, from the bark of Aralia elata Seem. (Araliaceae): The structure-requirement in oleanolic acid glucuronide - saponins for the inhibitory activity. Chemical and Pharmaceutical Bulletin, 44(10), 1915-1922.

Young, D. S., \& Friedman, R. B. (2001). Effects of disease on clinical laboratory tests. 4th ed. AACC Press, Washington.

Yu, J., Wang, Y., Qian, H., Zhao, Y., Liu, B., \& Fu, C. (2012). Polyprenols from Taxus chinensis var. mairei prevent the development of $\mathrm{CCl}_{4}$-induced liver fibrosis in rats. Journal of Ethnopharmacology, 142(1), 151-160.

Yu, L. (2011). The antitumor effects of araloside A extracted from the root bark of Aralia elata on human kidney cancer cell lines. African Journal of Pharmacy and Pharmacology, 5(4), 462-467.

Zazharskyi, V. V., Davydenko, P. O., Kulishenko, O. M., Borovik, I. V., \& Brygadyrenko, V. V. (2019). Antimicrobial activity of 50 plant extracts. Biosystems Diversity, 27(2), 163-169.

Zhang, Y., \& Song, S. (2012). Cytotoxic triterpene saponins of Aralia elata. Planta Medica, 2012, 78

Zhang, Y., Peng, Y., Li, L., Zhao, L., Hu, Y., Hu, C., \& Song, S. (2013). Studies on cytotoxic triterpene saponins from the leaves of Aralia elata. Food Chemistry, 138(1), 208-213.

Zhang, Y., Han, F.-Y., Wu, J., \& Song, S.-J. (2018a). Triterpene saponins with a-glucosidase and PTP1B inhibitory activities from the leaves of Aralia elata. Phytochemistry Letters, 26, 179-183.

Zhang, Y., Wang, W., He, H., Song, X., Yao, G., \& Song, S. (2018b). Triterpene saponins with neuroprotective effects from a wild vegetable Aralia elata. Journal of Functional Foods, 45, 313-320.

Zhou, P., Xie, W., Luo, Y., Lu, S., Dai, Z., Wang, R., Sun, G., \& Sun, X. (2018). Protective effects of total saponins of Aralia elata (Miq.) on endothelial cell injury induced by TNF- $\alpha$ via modulation of the PI3K/Akt and NF- $\mathrm{KB}$ signalling pathways. International Journal of Molecular Sciences, 20(1), 36. 